\title{
Correspondence
}

ChINA \& WTO ReV. 2019:1; 167-182

http://dx.doi.org/10.14330/cwr.2019.5.1.08

pISSN 2383-8221 • elSSN 2384-4388

China and WTO Review

\section{Statutory Safeguards and Privileges for Developing Countries in the WTO Dispute Settlement System}

\author{
Kashif I. Zadi* \& Alexandra J. Davis ${ }^{* *} \&$ Ali R. Ansari ${ }^{* * *}$
}

The era of globalization has created a proverbial 'rush' to utilize trade and investment in developing nations. Growing fear over the abuse of developed nations' bargaining power in these areas led the WTO to adopt remedial measures ensuring the protection of developing nations during disputes. The WTO's dispute settlement system is unequivocally the most comprehensive form of the resolution of disputes among its Member States. Despite the numerous privileges and safeguards offered to developing Members States, reluctance and a lack of understanding in using the WTO dispute resolution process remain within these nations. This paper explains the options available to these nations, in an attempt to attract to use the dispute resolution process, and offers key insight on future amendments that can facilitate developing Member's participation in the future. It will further articulate the statutory safeguards and favors provided to developing countries in DSS.

Keywords: WTO, Dispute Settlement System, Developing Nation, DSU, Safeguard

* SJD candidate at Zhejiang University Ganghua Law School, China. LL.B./LL.M. (Punjab Univ. Pakistan). ORCID: https://orcid.org/0000-0002-6492-4195. The author may be contacted at: kashifimranoo1@hotmail.com/Address: Room No 315, Building No 10 International Dormitory, XiXi Campus, Zhejiang University, Wensan Road, West Lake District, Hangzhou, 310007 P.R. China.

** Attorney-at-Law (New York Bar); LL.M. candidate at Zhejiang University Guanghua Law School (China). J.D. (Tulane). ORCID: https://orcid.org/0000-0001-7037-978X. The author may be contacted at: adavis31@tulane.edu/Address: Room No 131, Building No. 10 International Dormitory, XiXi Campus, Zhejiang University, Wensan Road, West Lake District, Hangzhou, 310007 P.R. China.

*** SJD candidate at Zhejiang University Guanghua Law School (China). LL.B. (Karachi Univ., Pakistan), Master of Commerce (Sindh Univ., Pakistan). ORCID: https://orcid.org/0000-00029931-4450. The author may be contacted at: ara_7@live.com/Address: Room No.301, Building No. 10 International Dormitory, XiXi Campus, Zhejiang University, Wensan Road, WestLake District, Hangzhou, 310007 P.R. China. 


\section{Introduction}

International trade has grown fast for the last three decades. In order to regularize the international trade among nations, the World Trade Organization ("WTO") was created as a powerful institution which impacted the wider spectrum of economies at a global level. The WTO became an all-pervasive reality which possessed relevance for all segments of society. Today, the WTO plays its effective role to secure the interests of its Member States and stabilizes international trade on a global level. As such monumental economic growth inevitably results in more international disputes, the WTO's Dispute Settlement System ("DSS") serves as a major force and foundation for state rights. Unfortunately, however, developing countries are not participating actively in DSS although they are provided special and differential treatment under the WTO provisions. "Understanding on the Rules and Procedures Governing the Settlement of Disputes" ("DSU") deals with settlement of disputes in the WTO. It has many provisions which have significant value for developing countries and should be utilized by these nations to better ensure continued growth and protection of viable resources within their lands. This essay will articulate the statutory safeguards and favors provided to developing countries in DSS. It further aims to suggest provocative and tentative ideas for increasing the participation of developing countries in DSS.

\section{Evolution}

As heavy duties, sanctions and restrictions were imposed by many nations on foreign trade after World Wars I and II, international trade drastically declined and nations faced economic crises. ${ }^{1}$ Then, International Trade Organization was constituted to handle economic issues. However, due to the complexities of the ratification process and opposite public opinion, ${ }^{2}$ it failed to operate. In 1947, an agreement was signed to regulate international trade and tariffs among 22 countries in United Nations Conference, which was called the General Agreement on Trade and Tariff ("GATT"). ${ }^{3}$ The idea later became practical and operational at Geneva in January 1948. Several multi-national negotiations were held between different countries after the GATT was created. ${ }^{4}$ International trade was basically regulated by the GATT before the WTO was created by Uruguay Round of 
Multilateral Trade Negotiation with an agreement of 117 countries on April $15,1994^{5}$ and entered into force on January $1,1995{ }^{6}$ At present, there are one hundred and sixty four (164) members of the WTO which represents ninety-eight percent of the world's trading power. ${ }^{7}$ It handles the "Trade Related Aspects of Investment Measures" ("TRIMs"); "Trade Related Aspects of Intellectual Property Rights" ("TRIPs"); "Trade in service"; the enforcements of several reforms ; the implementation of multilateral Trade agreements; ministerial conference after two years; Dispute Settlement; and "Management of Trade Policy Review Mechanism."

The WTO sets the ground rules for international trade. It is a rule based system which facilitates to avoid confusions, difficulties, turmoil, disorder, lawlessness and uncertainties. Its agreements provide a settled framework for international trade to Member countries. These are binding upon the sovereign nations within the agreed limits in the light of their national trade policies. Having a set of rules is advantageous to all nations as it implies transparency in the system. A legal framework has a lightening effect on developing and under-developed countries because they depend upon predictable protection by international law. It provides trade protections and sanctions upon more powerful governments, whereas small economic entities and developing countries are getting benefits from multilateral sources of disciplines.

The WTO is a negotiating platform. It provides opportunities for both removing roadblocks to make international trade much easier and smoother, and resolving trade issues and conflicts through negotiations rather than sanctions and long lasting litigations. The WTO, however, does not guarantee a successful outcome. Participant nations of the forum can only reach to the agreements through their own good faith. The Member countries cannot blame the WTO if any member does not perform its obligations or fails to fulfill its duties as per negotiations. $^{10}$

The WTO's remedial measures protect the interest of nations against unlawful and unfair trade. Before 1995, disputes were settled through the GATT in the light of procedural aspects which were formulated in Tokyo Round. ${ }^{11}$ After the WTO came into existence, DSS was introduced in the WTO Agreement to settle the disputes as an integral part of this institution. It is considered the "jewel in the crown" of the WTO as stated by Director-General Pascal Lamy. ${ }^{12}$ DSS has 
handled nearly six hundred cases within the period of twenty-three years. ${ }^{13}$ So, keeping in view the importance and relevance with this research, the details of DSS are given below.

\section{DSS in General}

DSS is a major feature of the WTO. It prescribes a mechanism to enforce rights and observe obligations. Member States use DSS to highlight illegal measures taken against them by other Members and to enforce existing international trade obligations. ${ }^{14}$ The mechanism has ensured the long term welfare of the Member States by enforcing the trade liberalization commitments. The general and public interest in DSS shows its importance. ${ }^{15}$ Many jurists consider it as the backbone and core lynchpin of the multilateral trade system. ${ }^{16}$ This is illustrated in its mandatory application to all international trade disputes of Member States. Consequently, it is more successful than any other such institution of the world. ${ }^{17}$

The dispute settlement procedure has been enumerated in DSU, ${ }^{18}$ whose primary purpose is to protecti multilateral trading system. ${ }^{19}$ It provides a speedy, active and result-oriented procedure to solve the disputes related the WTO Agreement. It has been appreciated as a model system for dispute settlement throughout the international spectrum where "right preserves over might." ${ }^{20}$ It protects rights and obligation of Members by consultation or dispute settlement. ${ }^{21}$

DSU is applied to the disputes of those agreements which are enumerated in its Appendix I, called the 'covered agreements.' It shall also apply to the matters relevant to the WTO agreements and any other combined agreement or understanding. ${ }^{22}$

\section{Participation of Developing Countries in Trade Disputes under the WTO}

The trade disputes have been sharply increasing between Member countries since 1995. Within the period of forty-seven years under the GATT, a total threehundred disputes were reported. ${ }^{23}$ After then (1995-2017), however, five hundred and thirty-seven cases were filed. ${ }^{24}$ The number of cases has nearly doubled in half amount of time under the new system. Members have started to participate in 
this system actively. Both developed and developing countries have utilized this mechanism in the recent past. Seventeen representations for consultations occurred in 2017 which are more than the requests filed in 2016 and $2015 .^{25}$

Among the 164 Member States of the WTO, ${ }^{26}$ approximately two-thirds are developing and least-developed countries. ${ }^{27}$ The WTO's statistical data shows that developed countries are using DSS more actively than the least developed and developing countries. The total number of the developed countries in the WTO is about twenty percent, but fifty-seven percent of total requests for consultation are made by them. Such trend continues through all parts of DSS. They made 56.7 percent of total Panel Requests. Furthermore, 58.5 percent of Panel Reports and 62.7 percent of Appellate Body Reports are concerned with developed countries. On the other hand, fifty-three percent memberships in the WTO is consisted of developing countries. However, they only represent 42.7 percent of consultation requests and 43.3 percent of requests for Panel. The Panel and Appellate Body Reports relevant to them consist of a total of 41.5 percent and 37.3 percent, respectively. The least-developed countries are twenty-two percent of total WTO membership. They have made only about 0.17 percent requests for consultation; neither panel request, panel report, nor Appellate Body Report are concerned with these nations. ${ }^{28}$

\section{Statutory Safeguards and Privileges for Developing Countries under DSS}

Developing countries have a huge volume of trade transactions and their role cannot be ignored in international trade. ${ }^{29}$ The 'Marrakesh Agreement' has recognized the value of developing and least-developed countries in the preamble. It specifically states: "There is need for positive efforts designed to ensure that developing countries and especially the least developed among them, secure a share in the growth in international trade commensurate with the needs of their economic development. ${ }^{, 30}$ It is applicable to all 'covered agreements' and is elaborated in the case of EC-Tariff Preferences. ${ }^{31}$ Inactive participation of developing countries in DSS will have a negative influence on the WTO's future. Therefore, the provisions of safeguards and privileges to developing countries must be highlighted for them to participate in DSS more actively. 
Benefits for developing countries are constituted in "Trade in Goods," 'GATT,' 'GATS,' 'TRIPS,' 'DSU,' "Trade Policy Review Mechanism" and "Ministerial Decisions and Declarations." But this paper mainly focuses on the provisions of DSU. There are many provisions in DSU which have significant value for developing countries in the process of case hearings. US - Underwear is the first case filed by a developing country, Costa Rica against the US. It is always considered a good example for other developing countries who are considering the remedial action against developed Members via DSS. ${ }^{32}$ The following are the provisions which are beneficial to developing countries for the settlement of disputes under DSU.

\section{A. Right to Invoke the Procedure of 1966 Decision}

The fast-tracked "Procedure of the Decision of 5th April 1966" may also be used by developing Members in any dispute against a developed Member. ${ }^{33}$ It is allowed after consultation stage to the Director-General. A panel may be constituted if no resolution is reached within 60 days. This method has been adopted by the WTO in solving EC-Bananas. ${ }^{34}$ The decision also provides that if the developed country failed in implementing the rulings, the aggrieved party can avail any other remedial measure. ${ }^{35}$ It is a procedural safeguard provided to the developing countries to solve their disputes against the developed country in DSS.

\section{B. Special Attention during Consultation}

Consultation is a pre-panel stage and mostly done privately between the Members. It is generally considered outside the jurisdiction of Panel and Appellate Bodies. Developing Members, however, need to strongly emphasize DSU. Article 4 of DSU provides: "During consultations Members should give special attention to the particular problems and interests of developing country." ${ }^{, 36}$ Dispute Settlement Body ("DSB") can entertain the complaint of a developing country with regard to consultation. EC-Trade Description of Scallops is a major example of privilege for developing countries under Article 4. Chile complained: "Its request for consultations with another developed Member had been disregarded by the Communities thus discriminating against and impairing Chile's interests in deviation from the provisions of Article 4.10 of the DSU. ${ }^{, 37}$ DSB considered the complaint of Chile in its meeting. ${ }^{38}$ 


\section{Panelist from Developing Countries}

The constitution of penal and nature of panelists plays a vital role in the result of a dispute. DSU has safeguarded the right of developing countries. It provides: "If a dispute is between a developing country Member and a developed country Member, the panel shall, if the developing country Member so requests, include at least one panelist from a developing country Member." ${ }^{39}$ By adding the panel member from the developing country, the level of trust and satisfaction of developing countries will be increased on DSS.

\section{Sufficient time for Consultation and Presentation of Case}

Another related provision of DSU provides for a procedural concession by stating that if the developing country request, the Chairman of the DSB or the Panel has the authority to extend the period of consultation. ${ }^{40}$ This provision is considered mandatory. ${ }^{41}$ Pakistan utilized this article in its dispute with the US in 1995. When the US asked for establishing the panel in a meeting of DSB, Pakistan challenged the US' action on the ground that the consultations were in progress. Therefore, the establishment of the panel was deferred to the next meeting and consultations were held in Geneva. ${ }^{42}$

Article 12.10 of DSU describes that in a case where a developing country is the defendant, it must be given ample time for preparation and presentation of arguments. ${ }^{43}$ Developing countries can utilize this regulation in a dispute if they do not have resources, high powered attorneys and representatives to meet all the requirements of the case in such a limited time frame. Without Article 12.10, developing countries would not be able to adhere to timelines or be able to present a good case. It was positively considered in India - Quantitative Restrictions ( $Q R)$, where India requested additional time as the matter was of 'systemic importance,' covering many issues. Complainant, the US, opposed it because of DSU's clear deadline. However, the Panel concluded that India was entitled to an extra ten days. $^{44}$ 


\title{
E. Indication of Provisions of S\&DT in Report
}

Article 12.11 of DSU provides:

\begin{abstract}
Where one or more of the parties is a developing country Member, the panel's report shall explicitly indicate the form in which account has been taken of relevant provisions on differential and more-favourable treatment for developing country Members that form part of the covered agreements which have been raised by the developing country Member in the course of the dispute settlement procedures.
\end{abstract}

The Panel for the first time relied on this provision in its ruling in IndiaQuantitative Restrictions, while considering "the concept of special and differential treatment in relation to Article XVIII: B of GATT 1994." ${ }^{, 46}$ It has been determined that this provision has to be followed and the Panel shall consider it in its report.

\section{F. Particular Attention for Matters of Developing Countries}

Article 21 of DSU has also fixed that in the matters of dispute settlement special care must be given on issues which affect the interest of developing countries. ${ }^{47}$ It could be assumed that this is the direction to bodies/organs (DSB, Panel or Appellate Body) acting under this article to move in favor of developing nations. ${ }^{48}$ This article intends to provide the technical assistance to the developing countries. $^{49}$ In the case, Indonesia - Autos, the Arbitrator awarded the remedy to Indonesia under Article 21.2 of DSU by stating: "Particular attention should be paid to the interest of the developing country Members with respect to measures which has been subject to disputes settlement. ${ }^{, 50}$

\section{G. Further and Appropriate Actions for Developing Countries}

Article 21 of DSU also provides a protection to the developing countries. It states: "If the matter is one which has been raised by a developing country Member, the DSB shall consider what further action it might take which would be appropriate to the circumstances. ${ }^{, 51}$ When a developing country files a case, DSB would not only see the trading matter which is put before it, but also observe the impacts on the economic situation of that complaining country. ${ }^{52}$ This provision is binding in nature. Thus, DSB has the duty to facilitate the developing countries for the 
settlement of disputes. The developing countries must participate in DSS and invoke this provision for protecting their rights and dispute settlement.

\section{H. Assistance by the Secretariat}

Pursuant to Article 27 of DSU, the Secretariat of the WTO provides assistance for dispute settlement on the requests of its Members. In particular, it can facilitate the developing countries by providing special legal services for the settlement of disputes including highly qualified legal experts who can give assistance to ensure the continuous security of developing nation rights. ${ }^{53}$ They can get assistance under Article 27 to solve their disputes. It will be helpful for redressing the financial and legal expertise deficiency.

\section{Advisory Centre on WTO Law}

Advisory Centre on WTO Law ("ACWL") came to existence in 2001 in Geneva. ${ }^{54}$ It is another safeguard in addition to the special provisions. ACWL provides the best available legal aid to developing and least-developed countries, customs territories and economies in transition at a free or cheaper rate. The rate for legal services is different for all members according to their share in the world trade. ${ }^{55}$ Currently, thirty-five developing countries can get the assistance from ACWL. ${ }^{56}$ The Advisory Centre is funded by the WTO Members, but is not directly linked with the Secretariat. It plays an important role in the legal assistance of poor Members. It hires experts privately "on a pro-bono basis" to provide valued and specialized legal advices. It has provided its legal services in fifty-nine cases till now. ${ }^{57}$

\section{Reasons for Less Participation by Developing Countries}

As mentioned above, a developing country would get "special and differential treatment" at all steps of the dispute settlement. DSU has provided good offices, conciliation, and mediation for them. If consultations failed to find a solution, the Director-General or the Chairman (DSB) offers the services to solve the matter before the establishment of a panel. The Secretariat provides special legal services. It arranges the highly qualified legal expert on request. The Institute for Training and Technical Cooperation division hires a permanent and two part-time officials 
to assist them. The Secretariat also runs special training course on the dispute settlement system. Today, developing countries are prioritized under the WTO, but still facing practical difficulties bringing their issues in DSS.

Developing countries have many reasons for limited involvement in DSS. Some of the reasons are mentioned as follows:

1. DSU provides for a time-limited and rule-based process. However, it is a time-taking procedure which may cause loss to the nascent industries of developing countries. ${ }^{59}$

2. As developing countries have insufficient legal expertise, they avoid participating in the WTO dispute settlement procedure. ${ }^{60}$

3. The litigation costs in Geneva are separated from the expenditure of case which creates difficulties for developing countries. So, the lack of financial resources is another reason of lesser participation. ${ }^{61}$

4. Despite a favorable outcome in DSS, in practice, developing countries cannot expect the implementation and enforcement of the DSB recommendations for protecting their interests against the developed countries. ${ }^{62}$ The following are non-compliance cases of the developed countries: US-Gambling and Betting Services; US-Offfset Act (Byrd Amendment), US-1916 Act; Canada-Civilian Aircraft; US-Foreign Sales Corporation; Brazil-Aircraft, EC-Bananas; EC-Beef Hormones; US-Subsidies on Upland Cotton. $^{63}$

5. Provided remedies do not include any actual compensation for damages caused by the non-compliance. $^{64}$

These difficulties often preempt developing and least-developed countries from enjoying the privileges granted to them by the WTO. Although DSU provides more safeguards to developing nations in theory, understanding of these provisions by national legal counsel and their post-resolution effect in reality is still questionable. Thus, there is always room for improvement in the current system to protect the interests of developing and least-developed nations, which is so greatly needed.

\section{Recommendations and Suggestions}

As previously stated, there are some key issues plaguing meaningful participation of developing nations in DSS. More participation of developing nations must be two-fold: (1) there must be improvement within the developing nation itself and its 
understanding of the WTO law; and (2) there must be improvement to the system. The following are the proposals for improving this participation and opening the WTO process to the developing Member States in availing themselves of DSU.

1. The developing countries must utilize the Article 5 of DSU which gives opportunity of consultation and mediation by choosing the Director General of the WTO as mediator.

2. Developing countries must enhance their domestic legal capability on their own. The government may also engage with private law firms to pursue cases in the WTO.

3. All the developing countries must get membership in ACWL for legal assistance. Currently, only 35 developing countries are members. ${ }^{65}$

4. To improve dispute settlement process, developing countries must take steps in General Council.

5. General Council must determine some effective rules about the amount of cost and compensation to be paid when the developing and developed country are in conflict and the developing country is found to be true.

6. There must be some rules for joint retaliation by all developing countries when necessary to take measures against a developed country.

7. Developing countries must take steps for substantive interpretations of the Panels and Appellate Body.

8. Compliance issues must be resolved without delay.

9. The Panel should necessarily suggest specific recommendations.

By utilizing these proposals, many of the anxieties faced by developing nations can be alleviated. Undoubtedly, developing nations must help themselves, but the WTO must also support them to help themselves. Particularly, developing nations need a form of redress against developed nations that are non-compliant with the WTO sanctions.

\section{Conclusion}

The WTO was created for facilitating international trade and harmonizing the trade related issues. It has provided a very sound and useful mechanism to resolve the disputes among the Member States in the light of agreements. Its legal bodies are very committed in their working. There are certain favorable provisions for the developing countries in DSU for the settlement of disputes. In the presence 
of statutory safeguards for the settlement of dispute, however, the participation of developing countries is not satisfactory. In fact, it is difficult for the developing countries to prosecute their disputes under DSS due to the lack of financial resources, legal expertise, enforcement, compensation and loss of time. As a result, the proper implementation and improvement of these provisions are required to increase the participation of developing countries. The WTO and developed countries must consider the difficulties faced by the developing countries for their active participation in DSS.

\section{REFERENCES}

1. WTO, World Trade Report 5 (2013), available at https://www.wto.org/english/res_e/ booksp_e/world_trade_report13_e.pdf (last visited on Jan.10, 2019).

2. I. Trofimov, The Failure of the International Trade Organization (ITO): A Policy Entrepreneurship Perspective, 5 J. Politics \& L. 57 (2012).

3. J. Jackson, The Jurisprudence of GATT and the WTO: Insights on Treaty Law and Economic Relations 16 (1st ed. 2000).

4. A. Thakur \& N. Sharma, World Trade Organization and India 665 (2007).

5. GATT, Ministerial Declaration on the Uruguay Round (Sept. 20, 1986), available at https:// www.wto.org/gatt_docs/English/SULPDF/91240152.pdf (last visited on Jan.10, 2019).

6. WTO, UNDERSTANDING THE WTO 10 (3d ed. 2005), available at https://www.wto.org/english/ thewto_e/whatis_e/tif_e/understanding_text_e.pdf(last visited on Jan.10, 2019).

7. WTO AnNual Report (A Global Membership) 40 (2018), available at https://www.wto.org/ english/res_e/booksp_e/10_anrep18_membership_e.pdf (last visited on Jan.10, 2019).

8. Supra note 4, at 666.

9. J. Jackson, Legal Problems of International Economic Relations 1177 (4th ed. 2002).

10. Supra note 6, at 9-11.

11. N. Palmetr \& P. Mavroidis, Dispute Settlement in the World Trade Organization: Practice and Procedure 7-8 (2d. ed. 2004).

12. See WTO disputes reach 400 mark, WTO 2009 Press Release (Nov. 6, 2009), available at https://www.wto.org/english/news_e/pres09_e/pr578_e.htm (last visited on Jan.10, 2019).

13. R. Arie, The Effectiveness of WTO Dispute Settlement System: A Statistical Analysis 1 (EUI Working Papers Law 2017/11), available at https://ssrn.com/abstract=2997094 (last visited on Jan.10, 2019).

14. J. Merrills, International Dispute Settlement 211 (4th ed. 2005). 
15. P. Sutherland et al., The Future of The WTO: Addressing Institutional Challenges in the New Millennium 59 (2004), available at https://www.wto.org/english/thewto e/10anniv_e/future_wto_e.pdf (last visited on Jan.10, 2019).

16. See WTO's Unique System of Settling Disputes Nears 200 Cases in 2000, WTO 2000 Press Release, June 5, 2000, available at https://www.wto.org/english/news_e/pres00_e/pr180_ e.htm (last visited on Jan.10, 2019).

17. E.-U. Petersmann, The Gatt/WTO Dispute Settlement System: International Law, International Organizations and Dispute Settlement 163 (1997).

18. WTO Agreements, Annex 2, available at https://www.wto.org/english/tratop_e/dispu_e/ dsu_e.htm (last visited on Jan.10, 2019).

19. DSU art. 3.2.

20. J. Lacarte-Muro \& P. Gappah, Developing Countries and the WTO Legal and Dispute Settlement System: A View from the Bench, 3 J. InT'L Econ. L. 401 (2000).

21. DSU art. 1(1).

22. Id. art. 1(2).

23. WTO, Annual Report (2016), at 102, available at https://www.wto.org/english/res_e/ booksp_e/anrep_e/anrep16_e.pdf(last visited on Jan.10,2019).

24. WTO Annual Report (2017), at 106, available at https://www.wto.org/english/res_e/ booksp_e/anrep_e/anrep17_e.pdf. It explains that the total number of cases submitted till 2016 is 520. See also World Trade Organization Annual Report (2018), at 131, available at https://www.wto.org/english/res_e/booksp_e/14_anrep18_disputesettlement_e.pdf (all available at Jan. 10, 2019). It states that the new submitted cases are 17. In this way the total number is considered as 537 till 2017.

25. WTO Annual Report (2018): Dispute Settlement Activity in 2017, available at https:// www.wto.org/english/res_e/booksp_e/14_anrep18_disputesettlement_e.pdf (last visited on Jan.10, 2019).

26. WTO, Members and Observers, available at https://www.wto.org/english/thewto_e/whatis_ e/tif_e/org6_e.htm (last visited on Jan.10, 2019).

27. WTO, Understanding the WTO 93 (5th ed. 2015), available at https://www.wto.org/ english/thewto_e/whatis_e/tif_e/understanding_e.pdf (last visited on Jan.10, 2019).

28. Supra note 13, at 6.

29. Supra note 27, at 93.

30. Marrakesh Agreement, pmbl., available at https://www.wto.org/english/res_e/publications_ e/ai17_e/wto_agree_preamble_jur.pdf (last visited on Jan.10, 2019).

31. Appellate Body Report, European Communities - Conditions for the Granting of Tariff Preferences to Developing Countries, ๆ 161, WTO Doc. WT/DS246/AB/R (adopted Apr. 20, 2004), available at https://www.wto.org/english/tratop_e/dispu_e/246abr_e.doc Short summary is available at https://www.wto.org/english/tratop_e/dispu_e/cases_e/ds246_e.htm (all last visited on Jan. 16, 2019). 
32. Appellate Body Report, United States - Restrictions on Imports of Cotton and Man-Made Fibre Underwear (US - Underwear), WTO Doc. WT/DS/24R \& WT/DS24/AB/R (adopted Feb. 25, 1997), available at http://www.worldtradelaw.net/reports/wtoab/us-underwear(ab). doc. Short summary is available at https://www.wto.org/english/tratop_e/dispu_e/cases_e/ ds24_e.htm (all last visited on Jan. 16, 2019).

33. DSU art.3.12.

34. Panel Report, ECC-Member States' Import Regimes for Bananas, WTO Doc. WT/DS32/R, available at https://www.wto.org/english/tratop_E/dispu_e/disp_settlement_cbt_e/a1s1p1_ e.htm\#eec_bananas (last visited on Jan.10, 2019).

35. Decision on Procedure under Article XXIII, B.I.S.D. 14S/18 (Apr. 5, 1966), available at https://www.wto.org/english/tratop_e/dispu_e/disp_settlement_cbt_e/a2s1p1_e.htm (last visited on Jan. 16, 2019). It is applicable to a dispute between developing and developed country contracting party.

36. DSU art. 4.10.

37. WTO, Minutes of Meeting of the DSB (Sept. 27, 1995), WTO Doc. WT/DSB/M/7 (Oct. 27, 1995), available at $\mathrm{https} / / /$ docs.wto.org/dol2fe/Pages/FE_Search/FE_S_S006.aspx?FullTex tHash $=1 \&$ MetaCollection=WTO\&SymbolList $=\% 22 \mathrm{WT} \% 2 \mathrm{fDSB} \% 2 \mathrm{fM} \% 2 \mathrm{f} 7 \% 22+\mathrm{OR}+\%$ $22 \mathrm{WT} \% 2 \mathrm{fDSB} \% 2 \mathrm{fM} \% 2 \mathrm{f} 7 * 022$ (last visited on Jan. 16, 2019). For details, see M. Footer, Developing Country Practice in the Matter of WTO Dispute Settlement, 35 J. WorLd TRADE 66 (2001).

38. Id.

39. DSU art. 8.10.

40. Id. art. 12.10 .

41. WTO, Note from the Secretariat, WTO Doc. WT/COMTD/W/77/Rev.1/Add.1/Corr.1 (adopted Feb. 4, 2002), available at https://docs.wto.org/dol2fe/Pages/FE_Search/FE_S_ S009-DP.aspx?language $=$ E\&CatalogueIdList $=21868,75336,69267,64560,46353,12283,129$ $4 \&$ CurrentCatalogueIdIndex $=0 \&$ FullTextHash $=($ lasted visited on Jan. 16, 2019).

42. Footer, supra note 37.

43. Supra note 42.

44. Panel Report, India - Quantitative Restrictions on Imports of Agricultural, Textile and Industrial Products (India - QR), WTO Doc. WT/DS90/R (adopted Sept. 22, 1999), available at https://docs.wto.org/dol2fe/Pages/SS/directdoc.aspx?filename=Q:/WT/ds/90r. pdf. Short summary is available at https://www.wto.org/english/tratop_e/dispu_e/cases_e/ ds90_e.htm (all last visited on Jan. 16, 2019).

45. DSU art. 12.11.

46. Supra note 45.

47. DSU art. 21.2.

48. Supra note 44 at 69.

49. H. Horn \& P. Mavroidis, Remedies in the WTO Dispute Settlement System and 
DeVeloping Countries InTERests 28 (1999).

50. Panel Report, Indonesia - Automobile, WTO Doc. WT/DS55/14 \& WT/DS59/13 (adopted July. 23, 1998), available at https://docs.wto.org/dol2fe/Pages/FE_Search/FE_S_S009Html.aspx?Id=49109\&BoxNumber=3\&DocumentPartNumber=1\&Language=E\&HasEngl ishRecord $=$ True $\&$ HasFrenchRecord $=$ True $\&$ HasSpanishRecord $=$ True $\&$ Window $=$ L $\&$ Previe wContext=DP\&FullTextHash=371857150\#. A short summary is available at https://www. wto.org/english/tratop_e/dispu_e/cases_e/ds54_e.htm (all last visited on Jan. 16, 2019).

51. DSU art. 21.7.

52. Id. art. 21.8 .

53. Id. art. 27.2.

54. ACWL, The ACWL's Mission, available at http://www.acwl.ch/acwl-mission (last visited on Jan.10, 2019).

55. Id. (The ACWL provides free advice on all WTO legal matters), available at http://www. acwl.ch/legal-advice (last visited on Jan.10, 2019).

56. Id. (Members), available at http://www.acwl.ch/members-introduction (last visited on Jan.10, 2019).

57. Id. (Assistance in WTO dispute settlement proceedings since July 2001), available at http:// www.acwl.ch/wto-disputes (last visited on Jan.10, 2019).

58. S. Acharya, Dispute Settlement Mechanism under WTO: Opportunities and Challenges 4 (2015), available at https://papers.ssrn.com/sol3/papers.cfm?abstract_id=2617187 (last visited on Jan.10, 2019).

59. R. Rajesh Babu, Remedies under the WTO Legal System 369 (2012).

60. K. Mitchell, Developing Country Success in WTO Disputes, 47 J. World Trade 81 (2013), available at https://heinonline.org/HOL/LandingPage?handle=hein.kluwer/jwt0047\&div $=7 \& \mathrm{id}=$ \&page $=($ last visited on Jan. 10, 2019).

61. G. Shaffer, Developing Country Use of the WTO Dispute Settlement System: Why it Matters, the Barriers Posed, and its Impact on Bargaining 22 (2005), available at https:// www.ictsd.org/sites/default/files/downloads/2013/02/developing-country-use-of-the-wtodispute-settlement-system_shaffer.pdf (last visited on Jan.10, 2019).

62. Id.

63. See WTO Dispute Settlement: One-Page Case Summaries (2017), available at https://www. wto.org/english/res_e/publications_e/dispu_settlement_e.htm (last visited on Jan.10, 2019).

64. Supra note 61.

65. Supra note 58. 
